\title{
$\Delta$ Np73 overexpression promotes resistance to apoptosis but does not cooperate with PML/RARA in the induction of an APL- leukemic phenotype
}

\author{
Antonio R. Lucena-Araujo ${ }^{1,2}$, Juan L. Coelho-Silva ${ }^{2}$, Diego A. Pereira-Martins ${ }^{2}$, \\ Carolina Thomé ${ }^{3}$, Priscila S. Scheucher ${ }^{1}$, Ana P. Lange ${ }^{1}$, Helder H. Paiva ${ }^{1}$, Benjamin \\ T. Hemmelgarn ${ }^{4}$, Mariana C. Morais-Sobral ${ }^{5}$, Elisa A. Azevedo ${ }^{6}$, Pedro L. Franca- \\ Neto $^{2}$, Rafael F. Franca ${ }^{6}$, Cleide L. Silva ${ }^{3}$, Alexandre Krause ${ }^{1}$, Eduardo M. Rego ${ }^{1,3}$ \\ ${ }^{1}$ Department of Internal Medicine, Medical School of Ribeirao Preto, Brazil \\ ${ }^{2}$ Department of Genetics, Federal University of Pernambuco, Recife, Brazil \\ ${ }^{3}$ Center for Cell Based Therapy, University of Sao Paulo, Ribeirao Preto, Brazil \\ ${ }^{4}$ The Ohio State University, Columbus, USA \\ ${ }^{5}$ Department of Microbiology, Fundação Oswaldo Cruz, Centro de Pesquisas Aggeu Magalhães, Recife, Brazil \\ ${ }^{6}$ Department of Virology, Fundação Oswaldo Cruz, Centro de Pesquisas Aggeu Magalhães, Recife, Brazil \\ Correspondence to: Antonio R. Lucena-Araujo, email: araujoarl@hotmail.com
}

Keywords: acute promyelocytic leukemia, $\triangle \mathrm{Np} 73$, apoptosis, bone marrow transplantation, lentiviral gene transfer Received: May 18, $2016 \quad$ Accepted: November 30, $2016 \quad$ Published: December 27, 2016

\section{ABSTRACT}

Here, we evaluated whether the overexpression of transcriptionally inactive $\Delta$ Np73 cooperates with PML/RARA fusion protein in the induction of an APL-leukemic phenotype, as well as its role in vitro in proliferation, myeloid differentiation, and drug-induced apoptosis. Using lentiviral gene transfer, we showed in vitro that $\Delta$ Np73 overexpression resulted in increased proliferation in murine bone marrow (BM) cells from hCG-PML/RARA transgenic mice and their wild-type (WT) counterpart, with no accumulation of cells at G2/M or S phases; instead, $\Delta \mathrm{Np73-expressing} \mathrm{cells} \mathrm{had} \mathrm{a} \mathrm{lower}$ rate of induced apoptosis. Next, we evaluated the effect of $\Delta N p 73$ on stem-cell selfrenewal and myeloid differentiation. Primary BM cells lentivirally infected with human $\Delta N$ p73 were not immortalized in culture and did not present significant changes in the percentage of CD11b. Finally, we assessed the impact of $\Delta \mathrm{Np73}$ on leukemogenesis or its possible cooperation with PML/RARA fusion protein in the induction of an APLleukemic phenotype. After 120 days of follow-up, all transplanted mice were clinically healthy and, no evidence of leukemia/myelodysplasia was apparent. Taken together, our data suggest that $\Delta N p 73$ had no leukemic transformation capacity by itself and apparently did not cooperate with the PML/RARA fusion protein to induce a leukemic phenotype in a murine BM transplantation model. In addition, the forced expression of $\Delta N$ p73 in murine BM progenitors did not alter the ATRA-induced differentiation rate in vitro or induce aberrant cell proliferation, but exerted an important role in cell survival, providing resistance to drug-induced apoptosis.

\section{INTRODUCTION}

In the clinical setting, high expression of the NH2terminal truncated $\Delta \mathrm{Np} 73$ isoforms (alone or in association with full-length transcriptionally active TAp73, i.e., a high $\Delta \mathrm{Np} 73 / \mathrm{TAp} 73$ ratio) has been associated with poor prognosis in primary human tumors [1-3], including hematological malignancies [4-6]. Recently [7], we demonstrated that a high $\Delta \mathrm{Np} 73 / \mathrm{TAp} 73$ ratio is associated with inferior outcome in patients with acute promyelocytic leukemia (APL) treated with all-trans retinoic acid (ATRA) and anthracycline-based chemotherapy according to the International Consortium on APL 2005 protocol [8]. However, the mechanism through which $\triangle \mathrm{Np} 73$ leads to adverse outcomes in APL remains to be elucidated and if $\triangle \mathrm{Np} 73$ works as a driver oncogene in APL is unknown. 
Using lentiviral gene transfer and murine bone marrow (BM) transplantation, we evaluated whether the forced expression of $\triangle \mathrm{Np} 73$ cooperates with PML/RARA fusion protein in the induction of an APL-leukemic phenotype. We also investigated the role of $\Delta \mathrm{Np} 73$ in proliferation, myeloid differentiation, and drug-induced apoptosis.

\section{RESULTS AND DISCUSSION}

First, we evaluated the role of $\Delta \mathrm{Np} 73$ in cell proliferation. At the end of the fifth day of culture, the forced expression of human $\triangle \mathrm{Np} 73$ in hCG-PML/RARA and WT murine cells resulted in increased proliferation compared to respective controls (Figure 1A). Intriguingly, after subsequent cell cycle analysis, we found no accumulation of cells at $\mathrm{G} 2 / \mathrm{M}$ or $\mathrm{S}$ phases. On the other hand, number of cells at sub-G0 fraction was significantly lower in $\Delta \mathrm{Np} 73$-expressing cells than empty vector controls (Figure 1B). We subsequently validated these findings through annexin-V/propidium iodide staining method, demonstrating that the basal apoptosis rate (i.e., spontaneous apoptosis) was less pronounced in $\triangle \mathrm{Np} 73$ expressing cells, regardless the presence of PML/RARA fusion gene (Figure 1C).

These findings prompted us to investigate whether $\Delta \mathrm{Np} 73$ overexpression results in resistance to druginduced apoptosis. We performed an in vitro assay of apoptosis using cytarabine (Ara-C, IC50: $100 \mu \mathrm{g} / \mathrm{ml}$ ) as the apoptotic stimulus [9]. Twenty-four hours later, $\Delta \mathrm{Np} 73$ expressing cells had a lower rate of apoptosis than empty vector controls (Figure 2A-2B). Next, we examined genes related to apoptosis and cell cycle pathways that were differentially expressed between hCG-PML/RARA cells (expressing or not the human $\triangle \mathrm{Np} 73$ gene) upon Ara-C treatment. Using PCR array procedure, we identified a set of 42 genes (39 upregulated and three downregulated) differentially expressed in hCG-PML/RARA Np73expressing cells in comparison with empty vector control (Figure 2C). As expected, most of genes were linked to apoptosis pathways. Only three genes related to cell cycle arrest were modulated by the presence of $\Delta \mathrm{Np} 73$ in hCG-PM/RARA-positive cells (Mdm2, Cdkn2a (p21), Mtbp). Of interest, apoptosis-associated genes in Np73expressing cells belonged to both mitochondrial-mediated (intrinsic pathway) and receptor-mediated pathways (extrinsic pathway).

Next, we evaluated the effect of $\Delta \mathrm{Np} 73$ on stem cell self-renewal and myeloid differentiation. Primary BM cells from hCG-PML/RARA and WT mice infected with human $\Delta \mathrm{Np} 73$ were not immortalized in methylcellulose culture. At first plating, the final number of myeloid colonies was not different between $\Delta \mathrm{Np} 73$-expressing cells and their respective controls (Figure $3 \mathrm{~A}$ ). In addition, the formation of colonies in methylcellulose was not sustained after the third to fourth plating in none of the groups (Figure 3B). Nevertheless, the final number of $\Delta \mathrm{Np} 73$ - expressing myeloid colonies was significantly higher compared to their respective controls after adding Ara-C $100 \mu \mathrm{g} / \mathrm{ml}$ to the methylcellulose cultures (Figure 3C), corroborating the resistance to drug-induced apoptosis observed in liquid culture. To check whether the forced expression of $\Delta \mathrm{Np} 73$ affects myeloid differentiation, we evaluated the percentage of CD11b-positive cells using ATRA ( $1 \mu \mathrm{M}, 7$ days in liquid culture) as the standard stimulus for differentiation. Immunophenotypic analysis revealed that induced expression of human $\Delta \mathrm{Np} 73 \mathrm{did}$ not significantly change the percentage of CD11b-positive cells (Figure 3D).

Finally, we assessed the impact of $\triangle \mathrm{Np} 73$ on leukemogenesis or its possible cooperation in vivo with PML/RARA fusion protein in the induction of an APLleukemic phenotype by transplanting lethally irradiated NOD/SCID mice (10 animals per group) with $3 \times 10^{5}$ GFPpositive BM cells (with or without human $\triangle \mathrm{Np} 73$ ) from hCG-PML/RARA cells or WT mice, along with $2 \times 10^{5}$ recipient-type $\mathrm{BM}$ cells. Following repopulation (at day 21 after transplantation), hemoglobin levels $(\mathrm{P}=0.03)$ and platelet counts $(\mathrm{P}=0.044)$ were significantly higher in both groups of mice transplanted with WT cells, regardless of the presence of $\Delta \mathrm{Np} 73$ (Supplementary Table 1). Fortyfive days after transplantation, a higher percentage of $\Delta \mathrm{Np} 73$-expressing cells was detected in the peripheral blood of recipients compared to empty vector controls $(\mathrm{P}<0.05$, Figure 4A). However, after 120 days of followup [10-12], all transplanted mice were clinically healthy and, according to the Bethesda criteria for hematopoietic neoplasms in mice [13], no evidence of leukemia or myelodysplasia was apparent after morphological evaluation of BM or spleen cells. Immunophenotypic analysis of BM recipients' cells revealed no significant difference between $\Delta \mathrm{Np} 73$-expressing and non- $\Delta \mathrm{Np} 73$ expressing cells with respect to myeloid and lymphoid cell markers (Figure 4B).

The hypothesis that $\Delta \mathrm{Np} 73$ harbors oncogenic potential is based on classical in vitro and in vivo transformation assays that demonstrated a proliferative advantage and/or cell immortalization of $\Delta \mathrm{Np} 73$ expressing cells [14-16]. Other studies have suggested that differentiation, rather than proliferation and cell immortalization, dictates the oncogenic potential of $\Delta \mathrm{Np} 73$ [17]. By delaying or blocking differentiation, $\Delta \mathrm{Np} 73$ could prevent progenitors from reaching terminal differentiation, keeping these cells in a constant proliferative state and thereby enabling tumor development driven by cooperating oncogenes. Interestingly, $\Delta \mathrm{Np} 73$ has been associated with the initiation of metastasis in melanoma cells [18] and several lines of evidence support $\Delta \mathrm{Np} 73$ as an important determinant for apoptotic response to therapy [2, 9, 19]. Accordingly, cells from transgenic mice selectively deficient for the $\Delta \mathrm{Np} 73$ isoforms have been shown to be more sensitive to DNA-damaging agents and undergo increased p53-dependent apoptosis [20]. On 
the other hand, the ectopic expression of transcriptionally active TAp73 was able to reduce drug resistance to chemotherapy in metastatic melanoma cells, which expressed high levels of $\Delta N p 73$ [21]. In agreement with this finding, down-regulation of the $\Delta \mathrm{Np} 73$ isoforms by antisense techniques has been shown to enhance TP53/
TAp73-mediated apoptosis in cancer cells in response to chemotherapy [22, 23].

Here, we did not see evidence of malignant transformation of pre-leukemic PML/RARA-positive cells by the forced expression of $\triangle \mathrm{Np} 73$ in in vitro or in vivo experiments, but instead $\Delta \mathrm{Np} 73$ overexpression provided

A.

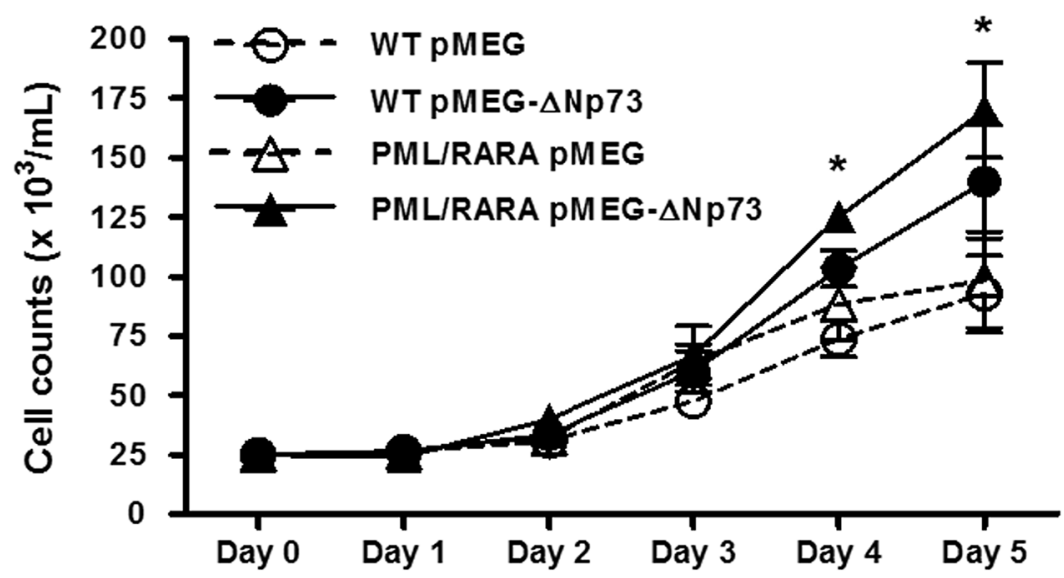

B.

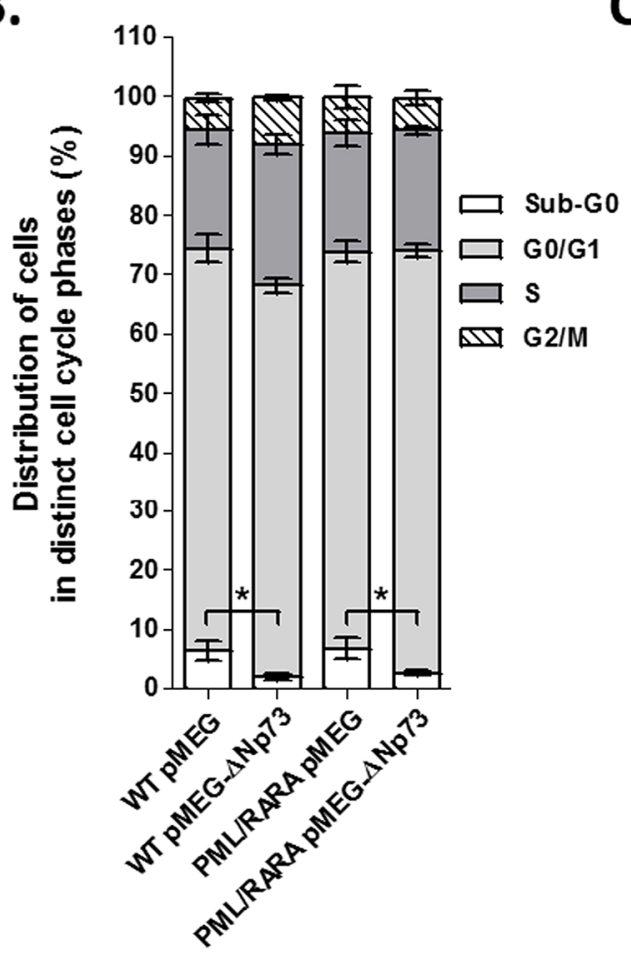

C.

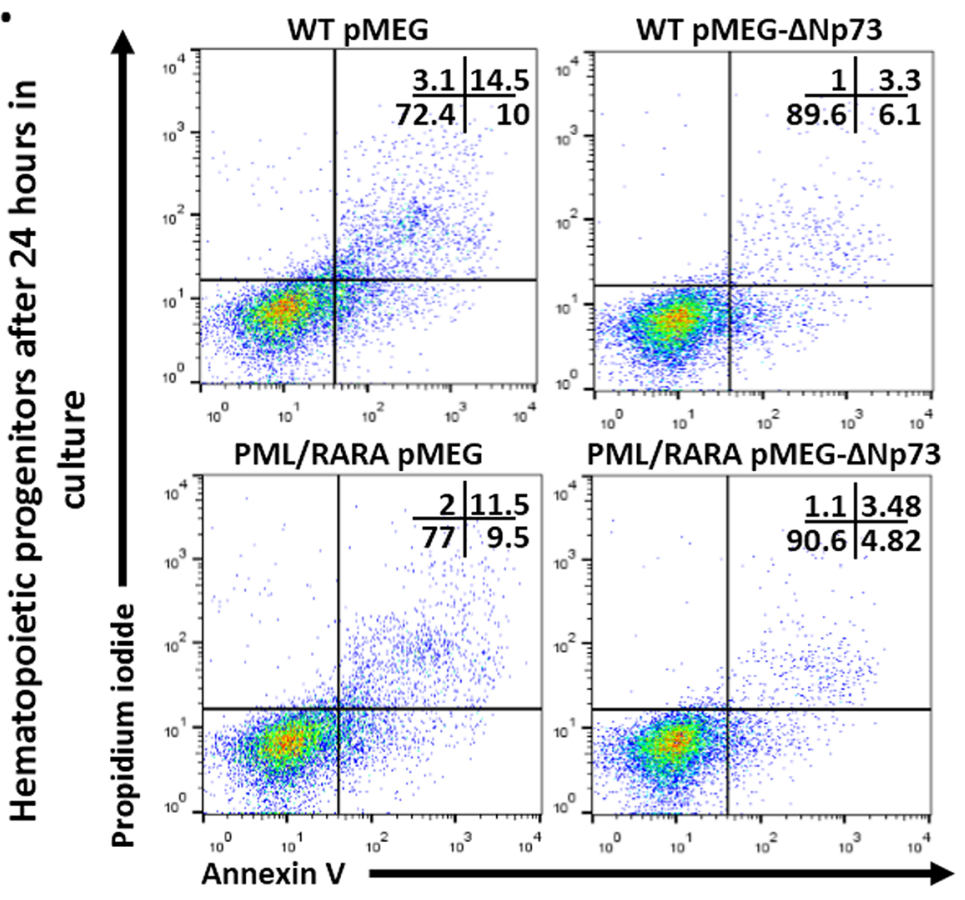

Figure 1: Characterization (in vitro assays) of primary hCG-PML/RARA-positive and WT hematopoietic progenitors infected with empty vector (pMEG) or pMEG- $\Delta$ Np73 lentiviruses. Growth curves A. and subsequent cell cycle analysis B. in vitro of hCG-PML/RARA-positive and WT cells. Data are expressed as mean \pm standard error of the mean $\mathbf{C}$. Representative analysis of the number of apoptotic cells by Annexin-V/propidium iodide binding assay according to the presence or absence of $\Delta \mathrm{Np} 73$. Primary BM cells from hCG-PML/RARA and WT mice were incubated with complete medium and no stimulus for apoptosis (spontaneous apoptosis) for 48-72 hours. * $P<0.05$. Note: Comparison among all four groups were performed for proliferation assays using Kruskal-Wallis test with Dunn's multiple comparison post test. No significant differences was observed between WT pMEG and PML/RARA pMEG or WT pMEG- $\triangle$ Np73 and PML/RARA pMEG- $\Delta$ Np73 groups. 

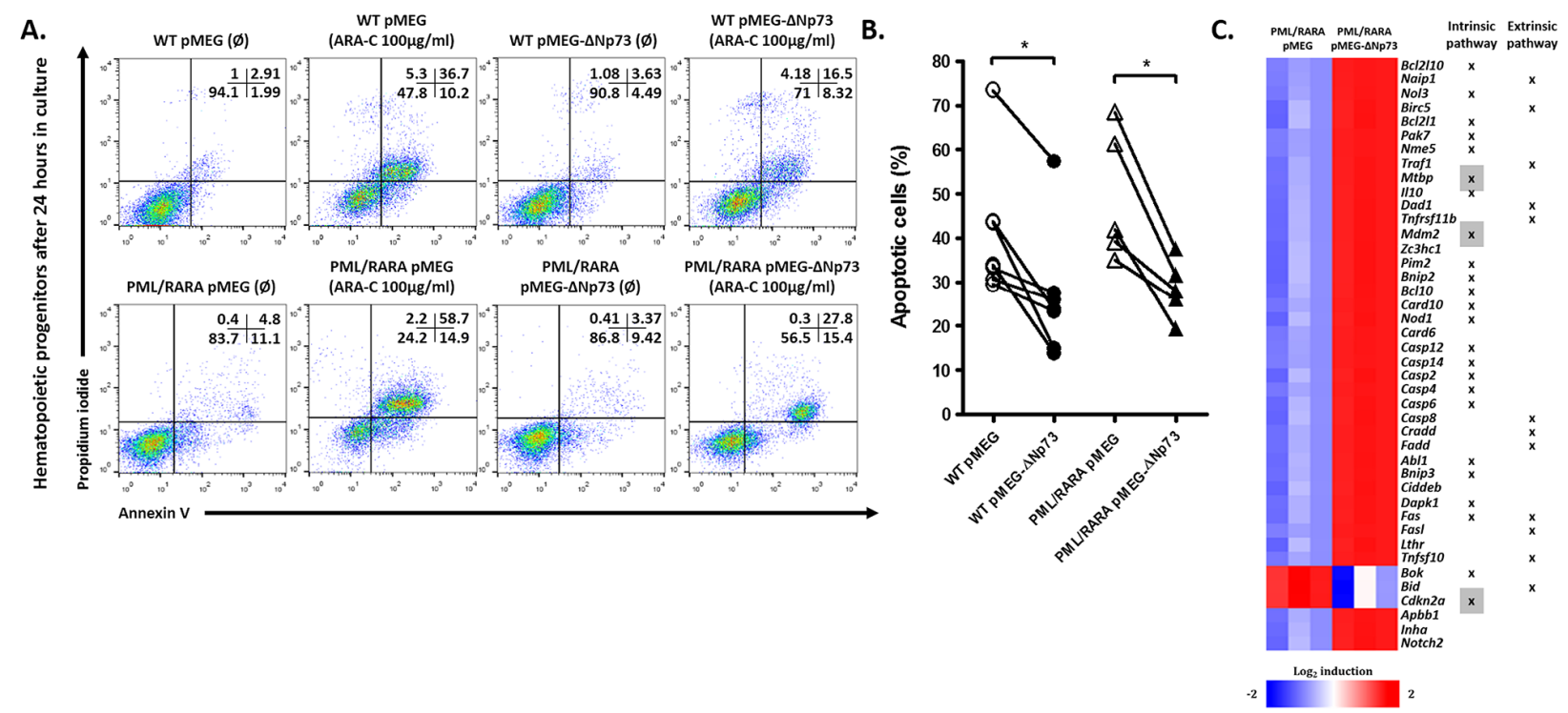

Figure 2: Drug-induced apoptosis assay. A. Representative example of one out of five independent experiments of apoptosis using Ara-C $100 \mu \mathrm{g} / \mathrm{ml}$ as standard stimulus for apoptosis. B. Percentage of apoptotic cells after $24 \mathrm{~h}$ in culture after apoptotic stimulus. C. Fold induction upon Ara-C treatment of the top genes differentially expressed in hCG-PML-RARA cells overexpressing or not the $\Delta$ Np73. Genes related to intrinsic or extrinsic pathways are indicated. Genes highlighted in gray represent those related to cell cycle control. (Ø) represents non treated samples. * indicates $P<0.05$.

A.

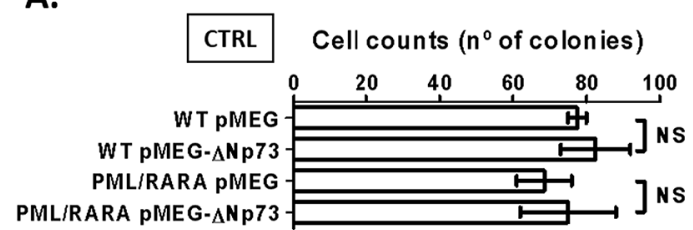

B.

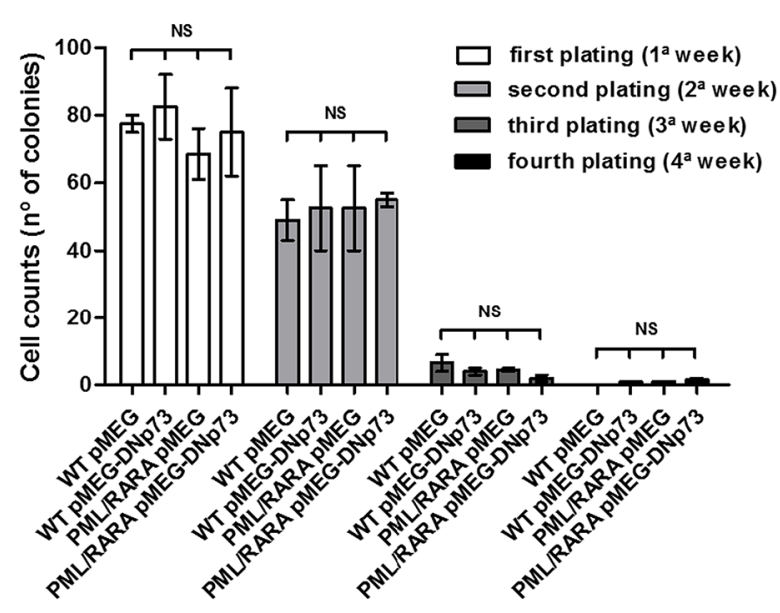

C.

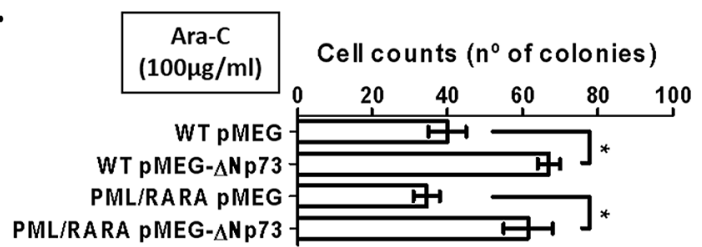

D.

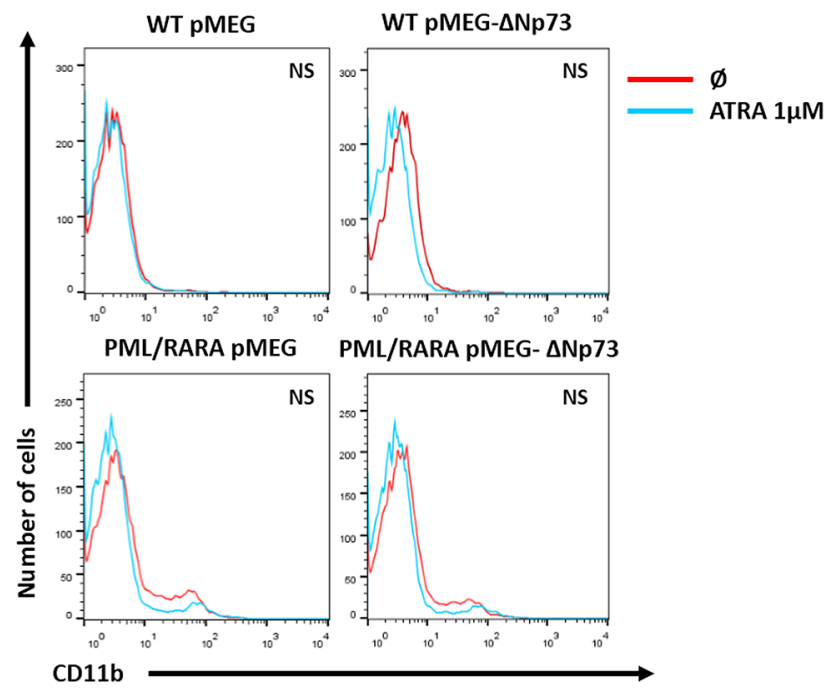

Figure 3: Effect of $\Delta \mathrm{Np} 73$ on stem cell self-renewal and myeloid differentiation. A. Number of colony-forming cells and B. clonogenic assay. Analysis of the number of colonies in methylcellulose. Bars represent the number of colonies counted after each plating. C. Colony forming assays performed in the presence of Ara-c $100 \mu \mathrm{g} / \mathrm{ml}$. D. Myeloid differentiation. Percentage of CD11b-positive cells in hCG-PML/RARA cells or WT primary cells (infected with empty vector, pMEG or pMEG- $\Delta$ Np73 lentiviruses) using ATRA $1 \mu \mathrm{M}$ as the standard stimulus for differentiation. (Ø) represent non treated samples. ${ }^{*} P<0.05$. NS: not significant. Note: Comparison among all four groups were performed using Kruskal-Wallis test with Dunn's multiple comparison post test. No significant differences was observed between WT pMEG and PML/RARA pMEG or WT pMEG- $\Delta$ Np73 and PML/RARA pMEG- $\Delta$ Np73 groups. 
an adaptive clonal advantage in the presence of a proapoptotic stimulus. One may argue that mice transplanted with PML/RARA-positive cells should develop an APLleukemic phenotype; nevertheless, it worth to note that only $8-12 \%$ of hCG-PML/RARA transgenic mice develop leukemia [24], and several evidence have demonstrated that the presence of PML/RARA fusion oncoprotein in transgenic mice is not per se sufficient to cause leukemia [25-27]. Interestingly, the protective effect of $\Delta \mathrm{Np} 73$ on cell death apparently was not influenced by the presence of the PML/RARA oncoprotein. Such an interaction would be expected, considering the intricate functional relationship between PML-p73-PML/RARA in APL blasts. At least when overexpressed, wild-type PML stabilizes p73 protein through acetylation, preventing its ubiquitination and subsequent degradation [28]. In APL, p73 stability/activity may be impaired mainly due to the disruption of PML-nuclear bodies by PML/RARA oncoprotein. Currently, whether distinct p73 isoforms (including the transactivation-deficient $\Delta \mathrm{Np} 73$ isoform) are differentially affected by impaired PML functions is unknown.

Although the aforementioned and others issues remain to be elucidated, it is undeniable the role of the TP53 family members and their intricate relationship in APL, in both onset and eradication of the disease. Gaillard et al. compared the gene expression and methylation profiles of purified promyelocyte populations from preleukemic MRP8-PML/RARA transgenic mice and showed that, in the absence of secondary lesions, PML/RARA has an overall limited impact on both the transcriptome and methylome [29]. The authors observed significant enrichment of the expression of cell cycle-related genes in PML/RARA promyelocytes, which led to expansion of the promyelocyte compartment and hypothesized that PML/RARA initiates leukemia by subtly shifting cell fate decisions within the promyelocyte compartment. Because our data suggest that $\Delta \mathrm{Np} 73$ plays an important role in cell survival, it is conceivable that $\Delta \mathrm{Np} 73$ participates in expansion of the promyelocytic compartment as an additional/secondary event. Following this reasoning, Ablain et al. [30] demonstrated that a functional Pml-p53 axis is required to eradicate leukemia-initiating cells in a mouse model of APL. Upon ATRA-induced PML/ RARA degradation, normal Pml elicits nuclear bodies reformation and induces a p53 response, which exhibits features of senescence, but not apoptosis. According to our hypothesis, even with the restoration of the nuclear bodies upon ATRA treatment and subsequent activation of Trp53 signaling, it is theoretically possible that the overexpression of $\Delta \mathrm{Np} 73$ protein impairs $\mathrm{p} 53$ tumor suppressor functions, and thus coffering survival advantage and/or resistance to chemotherapy to leukemic cells.

Taken together, these findings lead us to two major conclusions. First, $\triangle \mathrm{Np} 73$ had no leukemic transformation capacity by itself and apparently did not cooperate with the PML/RARA fusion protein to induce a leukemic phenotype in a murine BM transplantation model. Second, the forced expression of $\Delta \mathrm{Np} 73$ in murine BM progenitors
A.

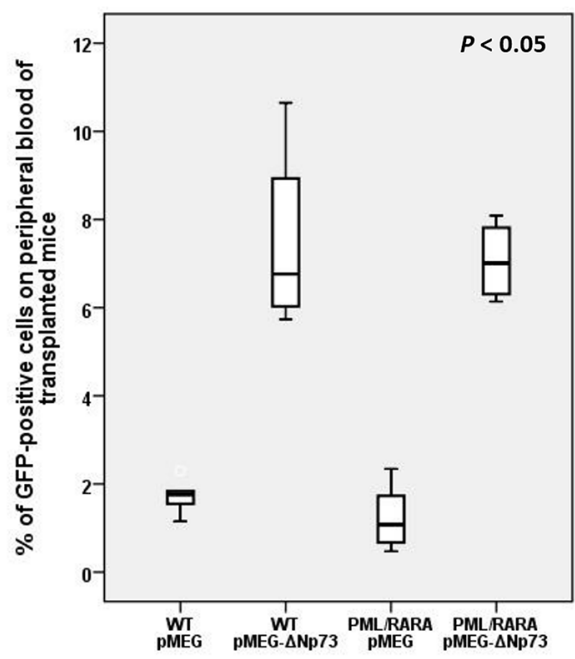

B.

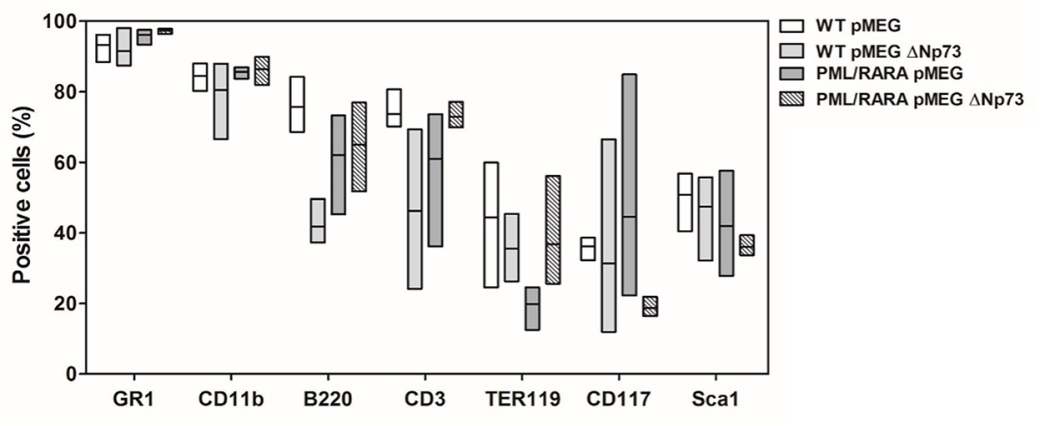

Figure 4: In vivo assays. A. Percentage of GFP-positive cells in the peripheral blood of lethally irradiated recipient mice transplanted with PML/RARA-positive or WT bone marrow cells in the presence or absence of $\triangle \mathrm{Np} 73$ overexpression. B. Immunophenotypic analysis of bone marrow recipients' cells with respect to myeloid and lymphoid cell markers after transplantation. Box plots show the summarized data for immunophenotypic analyses of bone marrow from survival mice that received a transplant of empty vector control (WT, 7 animals; hCG-PML/RARA, 8 animals) or $\triangle \mathrm{Np} 73$ (WT, 8 animals; hCG-PML/RARA, 6 animals). hGC-PML/RARA transplanted mice were not leukemic at the time of analysis. Bone marrow cells were stained for the indicated surface markers as indicated in the bottom of the figure. No significant difference between groups were detected. 
did not alter the ATRA-induced differentiation rate in vitro or induce aberrant cell proliferation, but exerted an important role in cell survival, providing resistance to drug-induced apoptosis. We and others [2, 3, 6, 7, 19, $23,31-34]$ support the idea that $\Delta \mathrm{Np} 73$ overexpression may be an important determinant of the clinical response to chemotherapy and may offer a therapeutic target for enhancing chemosensitivity in human tumors, including APL. Of course, in the current scenario, the combination of ATRA and arsenic trioxide must be tested in $\triangle \mathrm{Np} 73$ expressing cells in order to develop better strategies for patients who need special care, particularly those considered high-risk.

\section{MATERIALS AND METHODS}

\section{Lentiviral transduction of primary murine bone marrow cells}

\section{Mice}

Parental strain mice were bred and maintained at the Center for Cell Based Therapy Animal Facility. All experiments using mice were approved by the Institutional Animal Experimentation Ethics Committee (protocol number \#088/2007) and conducted according to national guidelines for care and use of laboratory animals. Cathepsin G-PML/RARA (hCG-PML/RARA) transgenic mice [24] and their wild-type (WT) counterparts, at 8 to 12 weeks of age, were used as donors of primary BM for lentiviral infection and subsequent in vitro assays and BM transplantation. Female NOD/SCID mice, older than 8 weeks of age, were used as recipients for BM transplantation model. hCG-PML/RARA transgenic mice and WT littermates were kindly provided by Dr. Pier Paolo Pandolfi (Beth Israel Deaconess Medical Center, Harvard Stem Cell Institute, Boston, USA). All animals were housed under specific pathogen free conditions in individually ventilated cages during the whole experiment and were maintained according to the Guide for Care and Use of Laboratory Animals of the National Research Council, USA, and to the National Council of Animal Experiment Control recommendations.

\section{Lentivirus production}

Recombinant lentivirus encoding $\triangle \mathrm{Np} 73$ gene was generated using pCDH1-MCS1-EF1-GFP-Puro (pMEG) (Supplementary Figure 1A) self-inactivating lentivector (\#CD713B-1; System Biosciences, Mountain View, CA, USA) in $293 \mathrm{~T}$ cells by following the three-plasmid packaging procedure as described elsewhere [35]. Briefly, the cDNA encoding hemagglutinin (HA)-tagged- $\Delta \mathrm{Np} 73$ was subcloned into $\mathrm{Xbal}$ and BamHI sites downstream to murine stem cell virus (MSCV) promoter. The complete sequence of $\Delta \mathrm{Np} 73$ gene was synthesized and fully sequenced in both directions by GenScript (Piscataway
Township, NJ, USA). In addition to the MSCV promoter, the pMEG lentivector harbors the enhanced GFP (EGFP) gene and the puromycin resistance gene (PURO) under the control of the constitutive human elongation factor $1 \alpha$ (EF1) promoter. pMEG-lentivector (containing or not the encoding $\Delta \mathrm{Np} 73$ gene; $22.5 \mu \mathrm{g} /$ plate), pCMV $\Delta \mathrm{R} 8.74$ expressing HIV gag/pol, Rev and tat (15 $\mu \mathrm{g} /$ plate), and pMD2G vector expressing VSV-G ( $8 \mu \mathrm{g} /$ plate) were transfected into five $100 \mathrm{~mm}$ culture dishes containing $293 \mathrm{~T}$ cells using Lipofectamine 2000 (Invitrogen), according to manufacturer recommendations. Twentyfour hours later, the fresh lentiviral particle-containing supernatants were collected, filtered through $0.45-\mu \mathrm{m}$ filters (Sarstedt, Nümbrecht, Germany) and used to infect the target cells.

\section{Primary BM cell isolation and lentiviral infection}

We used murine BM cells from healthy and agematched hCG-PML/RARA transgenic mice and their WT counterparts as the target for lentiviral infection. Briefly, mice were treated with $150 \mathrm{mg} / \mathrm{kg} 5$-fluorouracil for 5 days, sacrificed, and BM cells obtained by bone crushing. The cells were pre-stimulated for 48 hours in medium supplemented with $20 \%$ fetal bovine serum, murine interleukin-3 (6 ng/ml), murine interleukin-6 (10 ng/ml), and murine stem cell factor $(100 \mathrm{ng} / \mathrm{ml})$ in a humidified incubator at $37^{\circ} \mathrm{C}$ and $5 \% \mathrm{CO}_{2}$. Next, the murine $\mathrm{BM}$ cells were infected with empty vector (pMEG) or pMEG$\triangle N p 73$ lentiviruses for 4 to 6 hours, purified based on the expression of GFP protein (Supplementary Figure 1B), and posteriorly used for BM transplantation and in vitro assays.

\section{Western blotting and antibodies}

Whole-cell lysates were prepared as previously described [36]. Mouse anti- $\beta$-actin (sc-81178) was purchased from Santa Cruz Biotechnology (Santa Cruz, CA, USA) and horseradish peroxidase-conjugated secondary antibody horse anti-mouse IgG (\#7076) was purchased from Cell Signaling (Beverly, MA, USA). Anti-HA (NH2-terminal)-HRP Antibody (R930-25) was purchased from Life Technologies (Carlsbad, CA, USA). The antibody-protein complex was detected using the ECL Western Blotting Detection Reagents (GE Lifesciences Amersham, Buckinghamshire, Buckinghamshire, England).

\section{In vitro assays}

\section{Cell proliferation assay}

Cell suspensions containing $1 \times 10^{5}$ cells $/ \mathrm{mL}$ of highly purified murine BM cells were seeded in triplicate in $25 \mathrm{~cm}^{2}$ flask. Cell counts were performed daily for five days. Concomitantly, cell viability was determined by the Trypan blue dye exclusion method. Growth 
curves were drawn according to the number of cells $/ \mathrm{mL}$ taking in account the final number of cells/incubation time. To calculate the cell proliferation only viable cells were considered. Three independent experiments were performed for each group of cells.

\section{Cell cycle assay}

For the cell cycle analysis, $1 \times 10^{6}$ of highly purified murine BM cells were cultured in triplicate for 24 hours using complete medium in a 6-well plate and then were subjected to immunofluorescent staining of incorporated bromodeoxyuridine (BrdU) and 7-amino-actinomycin (7-AAD), followed by flow cytometric analysis using the BrdU Flow Kit (BD Biosciences, San Jose, CA, USA). Cells were incubated with $10 \mu \mathrm{M}$ of BrdU for 30 minutes, and then processed according to the manufacturer's recommendations.

\section{Apoptosis assay}

For the apoptosis analysis, $5 \times 10^{5}$ of highly purified murine BM cells were incubated in complete medium for 24 hours in the presence of vehicle or Ara-C $100 \mu \mathrm{g} / \mathrm{ml}$. The apoptosis rate was determined using the Annexin V-APC and propidium iodide (PI) binding assay (BD Biosciences, San Jose, CA, USA), and analyzed by flow cytometry. All experiments were performed in triplicate and in each sample a minimum of 10000 events were acquired in a FACSCalibur flow cytometer (BD Biosciences, San Jose, CA, USA).

\section{Colony-forming cell (CFC) assay}

CFCs were assayed in methylcellulose (Methocult M3434; STEMCELL Technologies Inc., Vancouver, Canada) supplemented with mIL-3 (6 ng/ml), mIL$6(10 \mathrm{ng} / \mathrm{ml})$, and $\mathrm{mSCF}(100 \mathrm{ng} / \mathrm{ml})$, following the manufacturer's recommendations. One thousand viable cells/dish were plated in triplicate. Colonies were evaluated microscopically on day 8 after plating by using standard criteria.

\section{Differentiation assay}

Cell suspensions containing $5 \times 10^{5}$ of highly purified murine BM cells were incubated in complete medium for seven days in the presence of ATRA $(1 \mu \mathrm{M})$. The differentiation rate was determined by immunophenotyping using the percentage of CD11bpositive cells (BD Biosciences, San Jose, CA, USA) as maturity marker. All experiments were performed in triplicate and in each sample a minimum of 10000 events were acquired in a FACSCalibur flow cytometer (BD Biosciences, San Jose, CA, USA).

\section{PCR array}

Both $\mathrm{RT}^{2}$ Profiler ${ }^{\mathrm{TM}}$ PCR Array Mouse Apoptosis ${ }^{\mathrm{TM}}$ and Mouse Cell Cycle (Qiagen, VA, USA) was employed to analyze the expression of a focused panel of genes in hCGPML/RARA cells infected with empty vector ( $\mathrm{pMEG)}$ or
pMEG- $\triangle$ Np73 lentiviruses. Samples were run at the ABI 7500 (Applied Biosystems, CA, USA). The data analysis was performed in SDS software 2.3 (SABiosciences). Genes were analyzed using two-way hierarchical cluster analysis based on the relative expression $\left(2^{-\Delta \Delta \mathrm{Ct}}\right)$ by Ward's method (JMP version 10.0.0, SAS Institute).

\section{Bone marrow transplantation}

A total of $3 \times 10^{5}$ of highly purified murine BM cells from WT mice and non-leukemic hCG-PML/RARA mice (containing or not $\Delta \mathrm{Np} 73$ ) along with $2 \times 10^{5}$ nontransfected cells of each background were injected into the lateral tail vein of lethally irradiated (3.5 Gy) NOD/ SCID recipient mice. Recipients were aged older than 8 up to 12-weeks. During the whole experiment, all animals were maintained under specific pathogen-free environment in individually ventilated cages and observed for signs of disease. Sparfloxacin $(10 \mu \mathrm{g} / \mathrm{ml})$ was given into the drinking water for 2 to 3 weeks after BM transplantation. Viability of mice was monitored daily. Engraftment of donor cells was monitored by tail vein bleeds and FACS analysis of GFP positive cells was performed after 45 days.

\section{Flow cytometry}

Freshly harvested BM cells from previously transplanted mice were suspended in phosphatebuffered saline contain $1 \%$ fetal bovine serum. The erythrocytes were lysed by alkaline lysis using AKC lysis buffer $(0.15 \mathrm{M} \mathrm{NH} 4 \mathrm{Cl}, 1 \mathrm{mM} \mathrm{KHCO} 3,0.1 \mathrm{mM} \mathrm{Na}-$ ethylenediaminetetraacetic acid, $\mathrm{pH}$ : 7.4). The nucleated cells were then stained using fluorescence labeled antibodies to Gr1, CD11b, B220, CD3, Ter119, CD117, Sca1, or isotype controls (BD Biosciences, San Jose, CA, USA) following the manufacturer's recommendations. The flow cytometric data were collected using a BD FACSCalibur, and analyzed using CellQuest Pro software (BD Biosciences, San Jose, CA, USA).

\section{Statistical analysis}

All calculations were performed using statistical package for the social sciences (SPSS) 19.0 software (IBM SPSS software, Chicago, IL, USA). All $P$-values were two sided with significance set to $5 \%$.

\section{ACKNOWLEDGMENTS}

We thank to Dr. Osvaldo Pompilio de Melo Neto and all members of his laboratory for their technical support in cloning experiments.

\section{CONFLICTS OF INTEREST}

The authors have no competing financial interests. 


\section{GRANT SUPPORT}

This investigation was supported by Fundacao de Amparo a Pesquisa do Estado de Sao Paulo (FAPESP, Grant \#2013/08135-2) and Conselho Nacional de Desenvolvimento Cientifico e Tecnologico (CNpQ, Grant $\# 573754 / 2008-0)$. A.R.L-A. received a fellowship from FAPESP (Grant \#2007/55067-1). J.L.C-S, D.A.P-M and P.L.F-N received fellowships from Fundação de Amparo a Ciência e Tecnologia de Pernambuco (FACEPE; Grants \#IBPG-1433-2.02/13) and CNpQ (Grant \#130614/20157), respectively.

\section{Authorship contributions}

A.R.L-A. performed experiments, analyzed and interpreted data, performed the statistical analyses, and drafted the article. J.L.C-S, D.A.P-M., C.T., P.S.S., A.P.L., H.H.P., B.T.H., M.C.M-S, E.A.A., P.L.F-N, R.F.F, C.L.S., and A.K. performed experiments, collected data, and reviewed the paper. E.M.R. reviewed the manuscript and gave the final approval of the submitted version.

\section{REFERENCES}

1. Buhlmann S, Putzer BM. DNp73 a matter of cancer: mechanisms and clinical implications. Biochim Biophys Acta. 2008; 1785:207-216. doi: 10.1016/j. bbcan.2008.01.002.

2. Leung TH, Wong SC, Chan KK, Chan DW, Cheung AN, Ngan HY. The interaction between C35 and DeltaNp73 promotes chemo-resistance in ovarian cancer cells. Br J Cancer. 2013; 109:965-975. doi: 10.1038/bjc.2013.397.

3. Soldevilla B, Diaz R, Silva J, Campos-Martin Y, Munoz C, Garcia V, Garcia JM, Pena C, Herrera M, Rodriguez M, Gomez I, Mohamed N, Marques MM, et al. Prognostic impact of DeltaTAp73 isoform levels and their target genes in colon cancer patients. Clin Cancer Res. 2011; 17:60296039. doi: 10.1158/1078-0432.CCR-10-2388.

4. Peters UR, Tschan MP, Kreuzer KA, Baskaynak G, Lass U, Tobler A, Fey MF, Schmidt CA. Distinct expression patterns of the p53-homologue p73 in malignant and normal hematopoiesis assessed by a novel real-time reverse transcription-polymerase chain reaction assay and protein analysis. Cancer Res. 1999; 59:4233-4236.

5. Sahu GR, Mishra R, Nagpal JK, Das BR. Alteration of p73 in acute myelogenous leukemia. Am J Hematol. 2005; 79:17. doi: 10.1002/ajh.20284.

6. Meier M, den Boer ML, Meijerink JP, Broekhuis MJ, Passier MM, van Wering ER, Janka-Schaub GE, Pieters R. Differential expression of $\mathrm{p} 73$ isoforms in relation to drug resistance in childhood T-lineage acute lymphoblastic leukaemia. Leukemia. 2006; 20:1377-1384. doi: 10.1038/ sj.leu.2404288.
7. Lucena-Araujo AR, Kim HT, Thome C, Jacomo RH, Melo RA, Bittencourt R, Pasquini R, Pagnano K, Gloria AB, Chauffaille ML, Athayde M, Chiattone CS, Mito I, et al. High DeltaNp73/TAp73 ratio is associated with poor prognosis in acute promyelocytic leukemia. Blood. 2015. doi: 10.1182/blood-2015-01-623330.

8. Rego EM, Kim HT, Ruiz-Arguelles GJ, Undurraga MS, Uriarte MR, Jacomo RH, Gutierrez-Aguirre H, Melo RA, Bittencourt R, Pasquini R, Pagnano K, Fagundes EM, Chauffaille $\mathrm{ML}$, et al. Improving acute promyelocytic leukemia (APL) outcome in developing countries through networking, results of the International Consortium on APL. Blood. 2013; 121:1935-1943. doi: 10.1182/ blood-2012-08-449918.

9. Lucena-Araujo AR, Panepucci RA, dos Santos GA, Jacomo RH, Santana-Lemos BA, Lima AS, Garcia AB, Araujo AG, Falcao RP, Rego EM. The expression of DeltaNTP73, TATP73 and TP53 genes in acute myeloid leukaemia is associated with recurrent cytogenetic abnormalities and in vitro susceptibility to cytarabine cytotoxicity. Br J Haematol. 2008; 142:74-78. doi: 10.1111/j.1365-2141.2008.07160.x.

10. Jacomo RH, Santana-Lemos BA, Lima AS, Assis PA, Lange AP, Figueiredo-Pontes LL, Oliveira LO, Bassi SC, Benicio MT, Baggio MS, Garcia AB, Falcao RP, Rego EM. Methionine-induced hyperhomocysteinemia reverts fibrinolytic pathway activation in a murine model of acute promyelocytic leukemia. Blood. 2012; 120:207-213. doi: 10.1182/blood-2011-04-347187.

11. dos Santos GA, Abreu e Lima RS, Pestana CR, Lima AS, Scheucher PS, Thome CH, Gimenes-Teixeira HL, SantanaLemos BA, Lucena-Araujo AR, Rodrigues FP, Nasr R, Uyemura SA, Falcao RP, et al. (+)alpha-Tocopheryl succinate inhibits the mitochondrial respiratory chain complex I and is as effective as arsenic trioxide or ATRA against acute promyelocytic leukemia in vivo. Leukemia. 2012; 26:451-460. doi: 10.1038/leu.2011.216.

12. Guibal FC, Alberich-Jorda M, Hirai H, Ebralidze A, Levantini E, Di RA, Zhang P, Santana-Lemos BA, Neuberg D, Wagers AJ, Rego EM, Tenen DG. Identification of a myeloid committed progenitor as the cancer-initiating cell in acute promyelocytic leukemia. Blood. 2009; 114:54155425. doi: 10.1182/blood-2008-10-182071.

13. Kogan SC, Ward JM, Anver MR, Berman JJ, Brayton C, Cardiff RD, Carter JS, de CS, Downing JR, Fredrickson TN, Haines DC, Harris AW, Harris NL, et al. Bethesda proposals for classification of nonlymphoid hematopoietic neoplasms in mice. Blood. 2002; 100:238-245.

14. Stiewe T, Zimmermann S, Frilling A, Esche H, Putzer BM. Transactivation-deficient DeltaTA-p73 acts as an oncogene. Cancer Res. 2002; 62:3598-3602.

15. Petrenko O, Zaika A, Moll UM. deltaNp73 facilitates cell immortalization and cooperates with oncogenic Ras in cellular transformation in vivo. Mol Cell Biol. 2003; 23:5540-5555. 
16. Tannapfel A, John K, Mise N, Schmidt A, Buhlmann S, Ibrahim SM, Putzer BM. Autonomous growth and hepatocarcinogenesis in transgenic mice expressing the $\mathrm{p} 53$ family inhibitor DNp73. Carcinogenesis. 2008; 29:211-218. doi: 10.1093/carcin/bgm236.

17. Zhang J, Chen X. DeltaNp73 modulates nerve growth factor-mediated neuronal differentiation through repression of TrkA. Mol Cell Biol. 2007; 27:3868-3880. doi: 10.1128/ MCB.02112-06.

18. Steder M, Alla V, Meier C, Spitschak A, Pahnke J, Furst K, Kowtharapu BS, Engelmann D, Petigk J, Egberts F, Schad-Trcka SG, Gross G, Nettelbeck DM, et al. DNp73 exerts function in metastasis initiation by disconnecting the inhibitory role of EPLIN on IGF1R-AKT/STAT3 signaling. Cancer Cell. 2013; 24:512-527. doi: 10.1016/j. ccr.2013.08.023.

19. Muller M, Schilling T, Sayan AE, Kairat A, Lorenz K, Schulze-Bergkamen H, Oren M, Koch A, Tannapfel A, Stremmel W, Melino G, Krammer PH. TAp73/Delta Np73 influences apoptotic response, chemosensitivity and prognosis in hepatocellular carcinoma. Cell Death Differ. 2005; 12:1564-1577. doi: 10.1038/sj.cdd.4401774.

20. Wilhelm MT, Rufini A, Wetzel MK, Tsuchihara K, Inoue $\mathrm{S}$, Tomasini R, Itie-Youten A, Wakeham A, ArsenianHenriksson M, Melino G, Kaplan DR, Miller FD, Mak TW. Isoform-specific p73 knockout mice reveal a novel role for delta Np73 in the DNA damage response pathway. Genes Dev. 2010; 24:549-560. doi: 10.1101/gad.1873910.

21. Tuve S, Racek T, Niemetz A, Schultz J, Soengas MS, Putzer BM. Adenovirus-mediated TA-p73beta gene transfer increases chemosensitivity of human malignant melanomas. Apoptosis. 2006; 11:235-243. doi: 10.1007/ s10495-006-3407-0.

22. Ishimoto O, Kawahara C, Enjo K, Obinata M, Nukiwa T, Ikawa S. Possible oncogenic potential of DeltaNp73: a newly identified isoform of human p73. Cancer Res. 2002; 62:636-641.

23. Zaika AI, Slade N, Erster SH, Sansome C, Joseph TW, Pearl M, Chalas E, Moll UM. DeltaNp73, a dominant-negative inhibitor of wild-type p53 and TAp73, is up-regulated in human tumors. J Exp Med. 2002; 196:765-780.

24. He LZ, Tribioli C, Rivi R, Peruzzi D, Pelicci PG, Soares V, Cattoretti G, Pandolfi PP. Acute leukemia with promyelocytic features in PML/RARalpha transgenic mice. Proc Natl Acad Sci U S A. 1997; 94:5302-5307.

25. Grignani F, De MS, Nervi C, Tomassoni L, Gelmetti V, Cioce M, Fanelli M, Ruthardt M, Ferrara FF, Zamir I, Seiser C, Grignani F, Lazar MA, et al. Fusion proteins of the retinoic acid receptor-alpha recruit histone deacetylase in promyelocytic leukaemia. Nature. 1998; 391:815-818. doi: $10.1038 / 35901$.

26. Grignani F, Ferrucci PF, Testa U, Talamo G, Fagioli M, Alcalay M, Mencarelli A, Grignani F, Peschle C, Nicoletti I, Pelicci PG. The acute promyelocytic leukemia-specific PML-RAR alpha fusion protein inhibits differentiation and promotes survival of myeloid precursor cells. Cell. 1993; 74:423-431.

27. Grisolano JL, Wesselschmidt RL, Pelicci PG, Ley TJ. Altered myeloid development and acute leukemia in transgenic mice expressing PML-RAR alpha under control of cathepsin G regulatory sequences. Blood. 1997; 89:376-387.

28. Bernassola F, Salomoni P, Oberst A, Di Como CJ, Pagano M, Melino G, Pandolfi PP. Ubiquitin-dependent degradation of p73 is inhibited by PML. J Exp Med. 2004; 199:15451557. doi: $10.1084 /$ jem.20031943.

29. Gaillard C, Tokuyasu TA, Rosen G, Sotzen J, VitalianoPrunier A, Roy R, Passegue E, de TH, Figueroa ME, Kogan SC. Transcription and methylation analyses of preleukemic promyelocytes indicate a dual role for PML/RARA in leukemia initiation. Haematologica. 2015; 100:1064-1075. doi: 10.3324/haematol.2014.123018.

30. Ablain J, Rice K, Soilihi H, de RA, Minucci S, de TH. Activation of a promyelocytic leukemia-tumor protein 53 axis underlies acute promyelocytic leukemia cure. Nat Med. 2014; 20:167-174. doi: 10.1038/nm.3441.

31. Casciano I, Mazzocco K, Boni L, Pagnan G, Banelli B, Allemanni G, Ponzoni M, Tonini GP, Romani M. Expression of DeltaNp73 is a molecular marker for adverse outcome in neuroblastoma patients. Cell Death Differ. 2002; 9:246-251. doi: 10.1038/sj.cdd.4400993.

32. Dominguez G, Garcia JM, Pena C, Silva J, Garcia V, Martinez L, Maximiano C, Gomez ME, Rivera JA, GarciaAndrade C, Bonilla F. DeltaTAp73 upregulation correlates with poor prognosis in human tumors: putative in vivo network involving p73 isoforms, p53, and E2F-1. J Clin Oncol. 2006; 24:805-815. doi: 10.1200/JCO.2005.02.2350.

33. Liu SS, Chan KY, Cheung AN, Liao XY, Leung TW, Ngan HY. Expression of deltaNp73 and TAp73alpha independently associated with radiosensitivities and prognoses in cervical squamous cell carcinoma. Clin Cancer Res. 2006; 12:3922-3927. doi: 10.1158/1078-0432. CCR-05-2573.

34. Uramoto H, Sugio K, Oyama T, Nakata S, Ono K, Morita M, Funa K, Yasumoto K. Expression of deltaNp73 predicts poor prognosis in lung cancer. Clin Cancer Res. 2004; 10:6905-6911. doi: 10.1158/1078-0432.CCR-04-0290.

35. Naldini L, Blomer U, Gage FH, Trono D, Verma IM. Efficient transfer, integration, and sustained long-term expression of the transgene in adult rat brains injected with a lentiviral vector. Proc Natl Acad Sci U S A. 1996; 93:11382-11388.

36. Thome $\mathrm{CH}$, dos Santos GA, Ferreira GA, Scheucher PS, Izumi C, Leopoldino AM, Simao AM, Ciancaglini P, de Oliveira KT, Chin A, Hanash SM, Falcao RP, et al. Linker for activation of T-cell family member2 (LAT2) a lipid raft adaptor protein for AKT signaling, is an early mediator of alkylphospholipid anti-leukemic activity. Mol Cell Proteomics. 2012; 11:1898-1912. doi: 10.1074/mcp. M112.019661. 